\title{
Rевевсн автіск: Adoption level of recommended practices of red gram by beneficiary and non-beneficiary farmers
}

\author{
S. Prashanth, S.G. Aski and S.H. Gotyal
}

Article Chronicle:

Received :

23.07.2020;

Revised:

25.09.2020;

Accepted :

14.10.2020

Key Words : Adoption level, Recommended practices, Red gram, Beneficiary, Nonbeneficiary farmers
SUMMARY : The research was conducted in Vijayapura district of Karnataka during the year 2019-20 with the sample size of 120 respondents. The findings revealed that, in case of beneficiary farmers about 41.67 per cent of the red gram farmers were found in high level of adoption category. While, In case of non-beneficiary farmers about 43.34 per cent of the red gram farmers were found in medium level of adoption level category. It is clear that, in case of beneficiary farmers about cent $(100.00 \%)$ per cent of the respondents have fully adopted red gram variety, recommended seed rate, intercultivation and weeding. Whereas, 83.33 per cent of the respondents have fully adopted recommended spacing, 76.67 per cent fully adopted pest management, 75.00 per cent fully adopted timely sowing and disease management, 73.33 per cent have fully adopted summer ploughing, 70.00 per cent fully adopted seed treatment, 66.67 per cent have fully adopted recommended dose of fertilizer, 51.67 per cent fully adopted nipping practice. It is clear that, in case of non-beneficiary farmers about cent $(100.00 \%)$ per cent of the respondents have fully adopted red gram variety and weeding. Followed by, 90.00 per cent have fully adopted recommended seed rate, 83.34 per cent have fully adopted intercultivation, 71.67 per cent have fully adopted seed treatment and recommended dose of fertilizer application, 70.00 per cent have fully adopted pest management, 68.33 per cent have fully adopted summer ploughing. Further about 56.67 per cent have fully adopted time of sowing, 55.00 per cent have adopted disease management.

How to cite this article : Prashanth, S., Aski, S.G. and Gotyal, S.H. (2020). Adoption level of recommended practices of red gram by beneficiary and non-beneficiary farmers. Agric. Update, 15(4): 319-324; DOI : 10.15740/ HAS/AU/15.4/319-324. Copyright@ 2020: Hind Agri-Horticultural Society.
Author for correspondence :

\section{S.G. Aski}

Department of

Agricultural Extension

Education, College of

Agriculture (UAS),

Vijayapur (Karnataka)

India

Email: askisubhash@

gmail.com

See end of the article for authors' affiliations 